\title{
PEMBENTUKAN DAN PEMBIDANGAN AKRONIM PADA KORAN POS KOTA
}

\author{
Ahmad Khoiril Anam¹, Yulia Agustin², Hilda Hilaliyah ${ }^{3}$ \\ Program Studi Pendidikan Bahasa Indonesia, \\ Fakultas Bahasa dan Seni, Universitas Indraprasta PGRI \\ ${ }^{1}$ Chairilanam45@gmail.com, ${ }^{2}$ hilda.unindra@gmail.com, ${ }^{3}$ yuliaagustin.unindra@gmail.com
}

\begin{abstract}
Abstrak
Penelitian ini bertujuan untuk mengetahui pembentukan dan pembidangan akronim yang terdapat pada penulisan berita koran Pos Kota. Jenis penelitian ini adalah penelitian deskriptif. Selain itu, metode yang digunakan dalam penelitian ini adalah metode kualitatif. Teknik analisis data yang digunakan dalam penelitian ini yaitu padan intralingual dan padan ekstralingual. Berdasarkan hasil penelitian yang telah dilakukan, dapat disimpulkan bahwa penghasil akronim terbanyak pada koran Pos Kota edisi Juli hingga Agustus 2018 berasal dari bidang forensik atau pertahan negara. Hal ini memang tidak dapat merepresentasikan bahwa kasus terbanyak pada negara ini adalah kasus kriminal atau hal-hal yang berhubungan dengan hukum. Akan tetapi, ini dapat menerangkan kepada semua bahwa bahasan yang paling banyak diulas pada koran ini adalah bahasan kriminal atau hal-hal yang berhubungan dengan urusan hukum. Dengan demikian, bisa jadi, kasus terbanyak pada negara ini adalah kasus-kasus yang berkenaan dengan urusan hukum. Selanjutnya disusul oleh bidang politik yang menempati urutan kedua. Ini pun menunjukkan bahwa tema politik sedang banyak diperbincangkan di negeri ini. mengingat saat ini, di Indonesia menjelang tahun politik.
\end{abstract}

Kata Kunci: Pembentukan, Pembidangan, Akronim

\begin{abstract}
This study aims to determine the formation and development of acronyms found in Pos Kota newspaper news writing. This type of research is descriptive research. In addition, the method used in this study is a qualitative method. The data analysis techniques used in this study were intralingual equivalents and extra lingual equivalents. Based on the results of the research that has been done, it can be concluded that the most acronym producers in the July to August 2018 edition of the Pos Kota newspaper come from the forensic or state defense sector. This does not represent that most cases in this country are criminal cases or matters related to law. However, this can explain to all that the most discussed topics for this person are criminal matters or matters relating to legal matters. Thus, perhaps, most cases in this country are cases related to legal matters. Then followed by the political sector which ranks second. This also shows that political themes are being discussed a lot in this country. considering the moment, Indonesia is approaching a political year
\end{abstract}

Keywords: Formation, Division, Acronyms 


\section{PENDAHULUAN}

Media massa merupakan sarana dan saluran resmi yang bertugas menyebarkan berita dan informasi kepada masyarakat luas. Kata Media adalah bentuk jamak dari medium yang berarti tengah atau perantara. Massa berasal dari bahasa Inggris yaitu mass yang berarti kelompok, kumpulan, atau orang banyak. Dengan demikian, pengertian media massa adalah sarana atau media yang digunakan oleh massa untuk berhubungan satu sama lain. Dalam hal ini, saluran resmi, baik berupa elektronik, cetak, maupun digital bertujuan untuk menyampaikan informasi. Yang termasuk media massa atau sarana komunikasi massa adalah surat kabar, majalah, radio, televisi, dan film. Kelima jenis media massa itu dalam literatur lama dikenal dengan sebutan The Big Five of Mass Media (Lima Besar Media Massa).

Seiring dengan perkembangan zaman, media massa senantiasa berkembang, baik dari segi sarana, informasi, hingga teknologinya. Hal ini menyebabkan jenis media yang digunakan pun senantiasa berkembang. Salah satu bukti perkembangan jenis media massa adalah dengan adanya berita daring (online) yang banyak di Indonesia. Hal ini ditunjukkan dengan munculnya The Big Six of Mass Media karena hadirnya internet yang melahirkan media siber (cybermedia, media online). Di samping itu, jenis media massa terdahulu masih kuat menunjukkan eksistensinya di kalangan masyarakat Indonesia. Salah satu jenis media massa tersebut adalah media cetak. Surat kabar atau koran merupakan salah satunya.

Surat kabar atau koran adalah salah satu jenis media cetak yang masih eksis di masyarakat. Menurut Yunus (2012: 29) surat kabar yaitu media komunikasi yang berisikan informasi aktual dari berbagai aspek kehidupan, seperti politik, ekonomi, kriminal, seni, olahraga, luar negeri, dalam negeri, dan sebagainya. Menurut Nurjayati (2014: 6) surat kabar adalah lembaran tercetak yang memuat laporan yang terjadi di masyarakat dengan ciri-ciri terbit secara periodik, bersifat umum, isinya aktual mengenal apa saja dan di mana saja di seluruh dunia untuk diketahui pembaca. Surat kabar pada umumnya terbit harian, sekalipun ada juga surat kabar mingguan. Selain itu, koran merupakan sebuah media massa yang di cetak dan disusun atau dibentuk dari kertas buram berukuran besar yang isinya memuat tentang informasi-informasi seputar kehidupan sehari-hari dan informasi sekitar, berita yang ada di dalamnya dicari dan ditulis oleh para jurnalis ataupun wartawan. Bentuknya terdiri dari kertas yang berukuran besar, dan dibentuk dari kertas buram dengan ukuran font tertentu. Selain itu, koran diterbitkan oleh suatu lembaga atau perusahaan tertentu seperti Koran Sindo atau Pos Kota untuk tujuan komersial. Karena ukurannya yang besar, koran biasanya di tekuk menjadi lebih kecil agar mudah dibawa. Selain itu, media massa ini terdiri kurang dari tiga puluh halaman sehingga bisa mudah ditekuk menjadi dua atau empat bagian. Selain itu dengan ukuran tulisan yang relatif kecil, bagi orang tua umumnya, mereka akan memakai kacamata untuk membaca surat kabar ini agar tulisan bisa mudah dibaca dan lebih jelas.

Untuk memudahkan dalam penyampaian informasi, koran menggunakan bahasa sebagai medianya. Bahasa disusun secara sistematis, singkat, dan mudah dipahami dengan tujuan agar pembaca mudah memahami informasi yang disampaikan oleh penulis berita. Kemampuan penulis dan editor sangat dituntut agar koran dapat disajikan secara maksimal. Dengan demikian, peran bahasa pada pembentukan koran sangatlah penting.

Kesempurnaan penulisan berita dan pengeditan dalam penyusunan surat tidaklah selalu berjalan dengan sempurna. Tentu permasalahan dalam penyusunan bahasa pasti ada, baik dalam intensitas yang tinggi, maupun rendah. Permasalahan tersebut meliputi 
kesalahan pengetikan, kesalahan tanda baca, kesalahan penulisan kata, hingga kesalahan pembentukan akronim.

Salah satu permasalahan di atas yang paling menarik perhatian penulis adalah pembentukan akronim. Menurut Arifin dan Aswinarko (2012: 52) akronim ialah singkatan dari dua kata atau lebih yang diperlakukan sebagai sebuah kata. Menurut Ahmad dan Abdullah (2012: 69) akronim adalah hasil pemendekan yang berupa kata atau dapat dilafalkan sebagai kata. Menurut Kridalaksana (2008: 5) akronim ialah kependekan yang berupa gabungan huruf atau suku kata atau bagian lain yang ditulis dan dilafalkan sebagai kata yang sesuai dengan kaidah fonotaktik bahasa bersangkutan; misalnya: ABRI, hankam, rudal (peluru kendali).

Merujuk hal tersebut, ini menarik dikaji karena penulis koran acap kali mencantumkan akronim di tiap-tiap naskah beritanya. Hal itu terjadi bukan karena tanpa tujuan atau sebatas iseng belaka, melainkan agar lebih meringkas penulisan tiap naskah beritanya. Hal ini dilakukan karena ruang yang tersedia pada tiap koran sangat terbatas sehingga cara ini dipilih untuk memaksimalkan ruang yang terbatas tersebut.

Pembentukan akronim menarik perhatian penulis karena banyak sekali akronimakronim baru yang berawal dari penulisan di media massa. Kadang-kadang banyak akronim yang memang belum baku atau belum terdaftar pada rema Kamus Besar Bahasa Indonesia. Selain itu, masalah yang ada adalah proses pembentukan akronim itu tidak mengacu pada aturan yang telah ditetapkan Pedoman Umum Ejaan Bahasa Indonesia.

Selain mengkaji letak kesalahan pembentukan akronim dan akronim-akronim baru tersebut, penulis juga berusaha menguak laras atau bidang apa saja yang acap kali memunculkan akronim ini. Dari sini akan memperlihatkan bidang apa saja yang paling banyak memunculkan akronim-akronim baru tersebut sehingga masyarakat familiar dengan akronim-akronim baru tersebut. Dengan demikian, akronim ini berpotensi menambah rema yang ada di Kamus Besar Bahasa Indonesia.

Dalam Pedoman Umum Ejaan Bahasa Indonesia (2016: 28-29) jenis-jenis akronim adalah sebagai berikut. 1) Akronim nama diri yang terdiri atas huruf awal setiap kata ditulis dengan huruf kapital tanpa tanda titik, 2) Akronim nama diri yang berupa gabungan suku kata atau gabungan huruf dan suku kata dari deret kata ditulis dengan huruf awal kapital, 3) Akronim bukan nama diri yang berupa gabungan huruf awal dan suku kata atau gabungan suku kata ditulis dengan huruf kecil.

Menurut Kridalaksana (2010: 170-172) klasifikasi akronim adalah sebagai berikut. 1) Pengekalan huruf pertama tiap komponen, 2) Pengekalan dua atau tiga huruf pertama tiap komponen, 3) Pengekalan suku pertama tiap komponen dengan pelepasan konjungsi. Aturan-aturan penulisan akronim telah diatur dalam Pedoman Umum Ejaan Bahasa Indonesia. Berikut merupakan aturan-aturan pembentukan akronim yang ada di dalamnya. 1) Akronim nama diri yang terdiri atas huruf awal setiap kata ditulis dengan huruf kapital tanpa tanda titik 2) Akronim nama diri yang berupa gabungan suku kata atau gabungan huruf dan suku kata dari deret kata ditulis dengan huruf awal kapital 3) Akronim bukan nama diri yang berupa gabungan huruf awal dan suku kata atau gabungan suku kata ditulis dengan huruf kecil.

Menurut Arifin dalam Anam dan Rosadi (2016: 28) mengemukakan bahwa yang dimaksud dengan singkatan ialah hasil menyingkat atau memendekkan berupa huruf atau gabungan huruf, seperti DPR, MPR, DPRD, SD, SMP, dan SMA. Menurut Kridalaksana (2010: 162) singkatan yaitu salah satu hasil proses pemendekan yang berupa huruf atau gabungan huruf, baik yang dieja huruf demi huruf maupun yang tidak dieja huruf demi huruf. Menurut Ahmad dan Abdullah (2010: 279) singkatan ialah bentuk yang 
dipendekkan yang terdiri dari satu huruf atau lebih. Menurut Kuntarto (2013: 76) singkatan ialah bentuk singkat yang terdiri atas satu huruf atau lebih.

Dalam Pedoman Umum Ejaan Bahasa Indonesia (2016: 26-28) jenis-jenis singkatan adalah sebagai berikut. 1) Singkatan nama orang, nama gelar, sapaan, jabatan, atau pangkat diikuti dengan tanda titik pada setiap unsur singkatan 2) Singkatan yang terdiri atas huruf awal setiap kata nama lembaga pemerintah dan ketatanegaraan, lembaga pendidikan, badan atau organisasi, serta nama dokumen resmi ditulis dengan huruf kapital tanpa tanda titik 3) Singkatan yang terdiri atas huruf awal setiap kata yang bukan nama diri ditulis dengan huruf kapital tanpa tanda titik 4) Singkatan yang terdiri atas tiga huruf atau lebih diikuti dengan tanda titik 5) Singkatan yang terdiri atas dua huruf lazim dipakai dalam surat-menyurat masing-masing diikuti oleh tanda titik 6) Lambang kimia, singkatan satuan ukuran, takaran, timbangan, dan mata uang tidak diikuti tanda titik. Sejalan dengan itu, menurut Kridalaksana (2010: 165-169) klasifikasi singkatan adalah sebagai berikut. 1) Pengekalan huruf pertama tiap komponen 2) Pengekalan huruf pertama dengan pelepasan konjungsi, preposisi, reduplikasi dan preposisi, artikulasi, dan kata 3) Pengekalan huruf pertama dengan bilangan, bila berulang, 4) Pengekalan huruf pertama dari tiap suku kata.

Atas dasar tersebut, penulis tertarik untuk melakukan kajian lebih lanjut mengenai pembentukan dan pembidangan akronim yang digunakan pada koran yang ada di Indonesia. Koran yang dijadikan sampel penelitian ini adalah Koran Pos Kota. Pos Kota dipilih karena surat kabar ini merupakan salah satu surat kabar yang kerap memunculkan akronim-akronim baru di dalamnya.

\section{METODE PENELITIAN}

Jenis penelitian ini adalah penelitian deskriptif dengan metode kualitatif. Secara umum metode penelitian dirangkum dalam tiga langkah. Pertama, mengajukan pertanyaan. Pertanyaan muncul ketika ada sesuatu yang menarik atau mengganjal pada sesuatu hal (Semiawan, 2010: 3), sehingga diperlukan jawaban lanjutan yang akan menerangkan ketidakjelasan tersebut. Kedua, mengumpulkan data, baik wawancara atau mengajukan pertanyaan tertulis yang sudah disiapkan sebelumnya bersama dengan pilihan jawabannya. Ketiga, menyajikan jawaban yang diperoleh sesudah data dan informasi dianalisis dengan cara yang benar, komprehensif dan logis (Semiawan, 2010: $3)$.

Objek pada penelitian ini adalah teks berita pada rubrik-rubrik terkait yang terdapat pada koran Pos Kota. Di samping itu, data yang digunakan pada penelitian ini adalah naskah dari rubrik-rubrik pilihan yang kerap memunculkan akronim-akronim baru. Sumber data diperoleh dari hasil observasi yang dilakukan oleh tim peneliti yang terdiri dari dosen dan mahasiswa melalui koran yang sebelumnya telah kami arsipkan.

Dalam penelitian ini, teknik pengumpulan data menggunakan dua metode, yaitu Studi Literatur dan Observasi. Teknik analisis data yang digunakan dalam penelitian ini yaitu padan intralingual dan padan ekstralingual. Metode padan menggunakan teknik hubung banding menyamakan (HBS) dan hubung banding membedakan (HBB). Selain dua teknik itu, metode ini mempunyai satu teknik lagi yaitu teknik hubung banding menyamakan hal pokok (HBSP), yaitu teknik yang bertujuan untuk mencari kesamaan hal pokok dari pembedaan dan penyamaan yang dilakukan dengan menerapkan teknik HBS dan HBB. Tujuan akhir dari banding menyamakan atau membedakan yaitu menemukan kesamaan pokok di antara data yang diperbandingkan itu (Mahsun, 2007: 118-119). 
Metode padan intralingual digunakan untuk menghubung-bandingkan unsurunsur dalam data penelitian yaitu satuan lingual yang mengandung permasalahan pembentukan akronim baru pada naskah berita koran Pos Kota untuk mendapatkan kesamaan hal pokok dari data-data tersebut. Hasil analisis ini akan menunjukkan klasifikasi bentuk pembentukan akronim berdasarkan struktur linguistik dan tata bahasanya.

\section{HASIL DAN PEMBAHASAN}

\section{Hasil}

Tabel 1 Kesesuaian Pembentukan Akronim dalam koran Pos Kota terhadap Pedoman Umum Ejaan Bahasa Indonesia

\begin{tabular}{lcc}
\hline \multicolumn{1}{c}{ Kategori } & $\begin{array}{c}\text { Jumlah Temuan Akronim } \\
\text { dalam Angka }\end{array}$ & $\begin{array}{c}\text { Jumlah Temuan } \\
\text { Akronim dalam Persen }\end{array}$ \\
\hline $\begin{array}{l}\text { Temuan akronim dalam koran Pos Kota } \\
\text { sesuai Pedoman Umum Ejaan Bahasa }\end{array}$ & 193 & $87,33 \%$ \\
$\begin{array}{l}\text { Indonesia } \\
\text { Temuan akronim dalam koran Pos Kota } \\
\text { tidak sesuai dengan Pedoman Umum } \\
\text { Ejaan Bahasa Indonesia }\end{array}$ & 28 & \\
\hline Jumlah & & $12,67 \%$ \\
\hline
\end{tabular}

Tabel 2 Pembentukan Akronim dalam koran Pos Kota Sesuai Bidang Pembentuknya

\begin{tabular}{lcc}
\hline $\begin{array}{c}\text { Kategori Pembentukan Akronim } \\
\text { Sesuai Bidangnya }\end{array}$ & $\begin{array}{c}\text { Jumlah Temuan Akronim } \\
\text { dalam Angka }\end{array}$ & $\begin{array}{c}\text { Jumlah Temuan Akronim } \\
\text { dalam Persen }\end{array}$ \\
\hline Bidang Forensik & 74 & $33,48 \%$ \\
Bidang Politik & 52 & $23,53 \%$ \\
Bidang Pemerintahan dan & 25 & $11,31 \%$ \\
Ketatanegaraan & & \\
Bidang Khas Geografis & 20 & $9,05 \%$ \\
Bidang Olahraga & 16 & $7,24 \%$ \\
Bidang Organisasi & 12 & $5,43 \%$ \\
Bidang Hiburan & 7 & $3,17 \%$ \\
Bidang Nama Diri & 6 & $2,72 \%$ \\
Bidang Teknologi & 5 & $2,26 \%$ \\
Bidang Hak Cipta dan Badan Hukum & 3 & $1,36 \%$ \\
Bidang Pendidikan & 1 & $0,5 \%$ \\
\hline Jumlah & 221 kata & $100 \%$
\end{tabular}

Berdasarkan tabel 1, penulis dapat mendeskripsikan beberapa temuan, di antaranya adalah sebagai berikut. Pertama, total atau jumlah temuan akronim yang penulis dapatkan sebanyak 221 kata. Dari 221 kata tersebut, penulis mendapatkan sebanyak 193 kata atau 87,33\% sudah terbentuk sesuai dengan Pedoman Umum Ejaan Bahasa Indonesia (PUEBI). Akan tetapi, yang belum sesuai dengan pembentukan akronim pada PUEBI mencapai 28 akronim atau sebesar 12,67\%. Ini menunjukkan bahwa kesalahan pembentukan akronim pada koran Pos Kota periode Juli dan Agustus tergolong sedikit. Akan tetapi, hal ini harus segera dibenahi agar penulisan atau 
pembentukan akronim sesuai dengan PUEBI. Berikut merupakan tabel yang dapat mendeskripsikan hasil temuan tersebut.

Hal lain yang kami amati adalah pemetaan atau pembidangan akronim. Maksudnya, kami mencoba untuk memecahkan bidang apa saja yang kerap memunculkan akronim. Setelah kami amati, kami menemukan beberapa temuan, yaitu: (1) bidang forensik, (2) bidang politik (3) bidang kepemerintahan atau ketatanegaraan (4) bidang khas geografis (5) bidang olahraga (6) bidang keorganisasian (7) bidang hiburan/seleberitis (8) bidang nama diri, nama orang, dan nama-nama sebutan lainnya (9) bidang teknologi dan internet (10) bidang lembaga yang menaungi hak cipta atau berbadan hukum lainnya (11) bidang.

Berdasarkan tabel 2, dapat diuraikan sebagai berikut. Pertama, bidang forensik atau pertahanan negara memunculkan akronim terbanyak, yaitu sebanyak 74 kata atau sebesar 33,48\%. Kedua, disusul oleh bidang politik yang memunculkan akronim sebanyak 52 kata atau sebesar 23,53\%. Ketiga, disusul oleh bidang kepemerintahan atau ketatanegaraan yang memunculkan akronim sebanyak 25 kata atau sebesar 11,31\%. Keempat, disusul oleh bidang khas geografis yang memunculkan akronim sebanyak 20 kata atau sebesar 9,05\%. Kelima, disusul oleh bidang olahraga yang memunculkan akronim sebanyak 16 kata atau sebesar 7,24\%. Keenam, disusul oleh bidang keorganisasian yang memunculkan akronim sebanyak 12 kata atau sebesar 5,43\%. Ketujuh, disusul oleh bidang hiburan/seleberitis yang memunculkan akronim sebanyak 7 kata atau sebesar 3,17\%. Kedelapan, disusul oleh bidang nama diri, nama orang, dan nama-nama sebutan lainnya yang memunculkan akronim sebanyak 6 kata atau sebesar $2,72 \%$. Kesembilan, disusul oleh bidang teknologi dan internet yang memunculkan akronim sebanyak 5 kata atau sebesar 2,26\%. Kesepuluh, disusul oleh bidang lembaga yang menaungi hak cipta atau berbadan hukum lainnya yang memunculkan akronim sebanyak 3 kata atau sebesar $1,36 \%$. Terakhir, disusul oleh bidang pendidikan yang memunculkan akronim sebanyak 1 kata atau sebesar $0,5 \%$.

\section{Pembahasan \\ Bidang Forensik}

Pembentukan akronim pada bidang forensik atau pertahanan negara memunculkan akronim terbanyak, yaitu sebanyak 74 kata atau sebesar 33,48\%. Salah satu contoh temuan penulis ambil dari rubrik kriminal pada edisi 6 Juli 2018 berjudul "Pembakaran Lahan Tak Beri Ampun". Setelah diamati, penulis menemukan beberapa akronim yang digunakan dalam rubrik ini, di antaranya adalah akronim Kombes Pol, Kamtibmas, Polresta, Bhabinkamtibmas, Bhabinsa TNI, Kapolresta, Kapolsek. Jika kita amati, akronim ini berasal dari bidang yang sama, yaitu bidang forensik. Pembentukan akronim pada kata-kata tersebut harus sesuai dengan Pedoman Umum Ejaan Bahasa Indonesia. Setelah diamati, pembentukan akronim pada kata akronim tersebut sudah benar karena akronim tersebut termasuk ke dalam akronim nama diri yang mengambil sebagian suku kata pada tiap kata yang telah dibentuk menjadi sebuah akronim. Akan tetapi, pembentukan akronim pada kata Pilkada belum benar karena akronim tersebut bukan termasuk ke dalam akronim nama diri sehingga tidak diperkenankan untuk ditulis dengan huruf kapital.

\section{Bidang Politik}

Bidang politik yang memunculkan akronim sebanyak 52 kata atau sebesar 23,53\%. Penulis memberikan temuan pada rubrik politik pada edisi 15 Juli 2018 berjudul "M. Taufik Pede Dipilih Gerindra Gantikan Sandiaga". Setelah diamati, penulis 
menemukan beberapa akronim yang digunakan dalam rubrik ini, di antaranya adalah akronim Wagub, Gerindra, Pileg, Bawaslu, caleg, dan Pemilu. Jika kita amati, akronim ini berasal dari bidang yang berbeda. Akronim wagub berasal dari bidang kepemerintahan, sedangkan Gerindra, Pileg, wagub, Bawaslu, caleg, dan Pemilu berasal dari bidang politik. Setelah diamati, pembentukan akronim pada kata Wagub, Gerindra, Pileg, dan Bawaslu sudah benar karena akronim tersebut termasuk ke dalam akronim nama diri yang mengambil sebagian suku kata pada tiap kata yang telah dibentuk menjadi sebuah akronim sehingga hanya huruf awal saja yang ditulis dengan huruf kapital. Selain itu akronim caleg sudah benar karena bukan merupakan nama diri sehingga sudah benar ditulis tanpa menggunakan huruf kapital. Akan tetapi, pembentukan akronim pada kata Pemilu belum benar karena akronim tersebut bukan termasuk ke dalam akronim nama diri sehingga tidak diperkenankan untuk ditulis dengan huruf kapital.

\section{Bidang Kepemerintahan atau Ketatanegaraan}

Bidang kepemerintahan atau ketatanegaraan memunculkan akronim sebanyak 25 kata atau sebesar 11,31\%. Rubrik politik pada edisi 18 Juli 2018 berjudul "9 Gubernur dan Wagub Terpilh Dilantik Jokowi". Setelah diamati, penulis menemukan satu akronim yang digunakan dalam rubrik ini, yaitu akronim wagub. Jika kita amati, akronim ini berasal dari bidang kepemerintahan. Setelah diamati, pembentukan akronim pada kata wagub belum benar karena akronim tersebut termasuk ke dalam akronim nama diri yang mengambil sebagian suku kata pada tiap kata yang telah dibentuk menjadi sebuah akronim sehingga hanya huruf awal saja yang ditulis dengan huruf kapital.

\section{Bidang Khas Geografis}

Bidang khas geografis yang memunculkan akronim sebanyak 20 kata atau sebesar 9,05\%. Rubrik olahraga pada edisi 21 Juli berjudul "Pegulat Putri Diminta Tampil Maksimal". Setelah diamati, penulis menemukan beberapa akronim yang digunakan dalam rubrik ini, di antaranya adalah akronim KONI, Jabar, Kaltim, Jatim, dan Kalsel. Jika kita amati, akronim ini berasal dari bidang yang berbeda. Akronim KONI berasal dari bidang olahraga, sedangkan Jabar, Kaltim, Jatim, dan Kalsel dari bidang geografis. Setelah diamati, pembentukan akronim pada kata KONI sudah benar karena akronim tersebut termasuk ke dalam akronim nama diri dan hanya mengambil huruf-huruf awal pada tiap kata yang dibentuk menjadi sebuah akronim sehingga semua huruf pada akronim tersebut harus ditulis menggunakan huruf kapital. Di samping itu, pembentukan akronim pada kata Jabar, Kaltim, Jatim, dan Kalsel sudah benar karena akronim tersebut termasuk ke dalam akronim nama diri yang mengambil sebagian suku kata pada tiap kata yang telah dibentuk menjadi sebuah akronim sehingga hanya huruf awal saja yang ditulis dengan huruf kapital.

\section{Bidang Olahraga}

Bidang olahraga yang memunculkan akronim sebanyak 16 kata atau sebesar 7,24\%. Rubrik olahraga pada edisi 24 Juli 2018 berjudul "Tim Tinju DKI Rebut 3 Emas". Setelah diamati, penulis menemukan beberapa akronim yang digunakan dalam rubrik ini, di antaranya adalah akronim GOR. Jika kita amati, akronim ini berasal dari bidang olahraga. Setelah diamati, pembentukan akronim pada kata GOR sudah benar karena akronim tersebut termasuk ke dalam akronim nama diri dan hanya mengambil hurufhuruf awal pada tiap kata yang dibentuk menjadi sebuah akronim sehingga semua huruf pada akronim tersebut harus ditulis menggunakan huruf kapital. 


\section{Organisasi}

Bidang keorganisasian yang memunculkan akronim sebanyak 12 kata atau sebesar 5,43\%. Rubrik olahraga pada edisi 6 Juli 2018 berjudul "Issi Jajal Velodrome". Setelah diamati, penulis menemukan beberapa akronim yang digunakan dalam rubrik ini, di antaranya adalah PB ISSI, KONI, KOI, INASGOC. Akronim ini menunjukkan nama badan organisasi. Setelah diamati, pembentukan akronim pada kata PB ISSI, KONI, dan KOI sudah benar karena akronim tersebut termasuk ke dalam akronim nama diri dan hanya mengambil huruf-huruf awal pada tiap kata yang dibentuk menjadi sebuah akronim. Jadi, semua huruf pada akronim tersebut harus ditulis menggunakan huruf kapital. Akan tetapi, pembentukan akronim pada kata INASGOC belum benar karena akronim tersebut termasuk ke dalam akronim nama diri yang menggabungkan huruf awal dan bagian suku kata dari tiap-tiap kata sehingga hanya diperkenankan untuk ditulis dengan huruf kapital pada awal kata saja.

\section{Hiburan/Entertainment}

Bidang hiburan/seleberitis yang memunculkan akronim sebanyak 7 kata atau sebesar 3,17\%. Rubrik hiburan pada edisi 21 Juli 2018 berjudul "Nadine Chandra Winata, 'Dimas Dulu SKSD, Sok Yakin'”. Setelah diamati, penulis menemukan beberapa akronim yang digunakan dalam rubrik ini, di antaranya adalah akronim sinetron. Jika kita amati, akronim ini berasal dari bidang hiburan. Setelah diamati, pembentukan akronim sinetron sudah benar karena bukan merupakan nama diri sehingga sudah benar ditulis tanpa menggunakan huruf kapital.

\section{Nama Diri}

Bidang hiburan/seleberitis yang memunculkan akronim sebanyak 7 kata atau sebesar 3,17\%. Rubrik politik pada edisi 24 Juli 2018 berjudul "Ma'ruf Amin Tolak Mundur". Setelah diamati, penulis menemukan beberapa akronim yang digunakan dalam rubrik ini, di antaranya adalah akronim Jokowi dan Pilpres. Jika kita amati, akronim ini berasal dari bidang yang berbeda. Akronim Jokowi berasal dari pemendekan nama orang, sedangkan Pilpres berasal dari bidang politik. Setelah diamati, pembentukan akronim pada kata Jokowi sudah benar karena akronim tersebut termasuk ke dalam akronim nama diri yang mengambil sebagian suku kata pada tiap kata yang telah dibentuk menjadi sebuah akronim sehingga hanya huruf awal saja yang ditulis dengan huruf kapital.

\section{Bidang Teknologi}

Bidang teknologi dan internet yang memunculkan akronim sebanyak 5 kata atau sebesar 2,26\%. Rubrik olahraga pada edisi 12 Juli 2018 berjudul "Peru Tak Mau Gegabah Butuh Ketenangan Lawan Prancis". Setelah diamati, penulis menemukan beberapa akronim yang digunakan dalam rubrik ini, di antaranya adalah akronim FIFA dan VAR. Jika kita amati, salah satu akronim ini berasal dari bidang yang teknologi, yaitu VAR. Setelah diamati, pembentukan akronim pada kata FIFA dan FAR sudah benar karena akronim tersebut termasuk ke dalam akronim nama diri dan hanya mengambil hurufhuruf awal pada tiap kata yang dibentuk menjadi sebuah akronim sehingga semua huruf pada akronim tersebut harus ditulis menggunakan huruf kapital.

Berdasarkan hasil tersebut, peneliti dapat menyimpulkan bahwa penghasil akronim terbanyak pada koran Pos Kota edisi Juli hingga Agustus 2018 berasal dari bidang forensik atau pertahan negara. Hal ini dapat merepresentasikan bahwa isu terbanyak pada negara ini di adalah kasus kriminal atau hal-hal yang berhubungan dengan hukum. Selain itu, ini dapat menerangkan kepada semua bahwa bahasan yang paling 
banyak diulas pada koran ini adalah bahasan kriminal atau hal-hal yang berhubungan dengan urusan hukum. Sebaliknya, isu yang paling sedikit dibicarakan adalah bidang pendidikan. Dengan demikian, bisa jadi, kasus terbanyak pada negara ini adalah kasuskasus yang berkenaan dengan urusan hukum. Selanjutnya disusul oleh bidang politik yang menempati urutan kedua. Ini pun menunjukkan bahwa tema politik sedang banyak diperbincangkan di negeri ini. mengingat saat ini, di Indonesia menjelang tahun politik.

\section{SIMPULAN}

Berdasarkan hasil penelitian yang telah dilakukan, dapat disimpulkan bahwa penghasil akronim terbanyak pada koran Pos Kota edisi Juli hingga Agustus 2018 berasal dari bidang forensik atau pertahan negara. Hal ini memang tidak dapat merepresentasikan bahwa kasus terbanyak pada negara ini adalah kasus kriminal atau hal-hal yang berhubungan dengan hukum. Akan tetapi, ini dapat menerangkan kepada semua bahwa bahasan yang paling banyak diulas pada koran ini adalah bahasan kriminal atau hal-hal yang berhubungan dengan urusan hukum. Dengan demikian, bisa jadi, kasus terbanyak pada negara ini adalah kasus-kasus yang berkenaan dengan urusan hukum. Selanjutnya disusul oleh bidang politik yang menempati urutan kedua. Ini pun menunjukkan bahwa tema politik sedang banyak diperbincangkan di negeri ini. mengingat saat ini, di Indonesia menjelang tahun politik.

\section{DAFTAR PUSTAKA}

Arifin, E. Z., \& Aswinarko. (2012). Penyuntingan naskah. Tangerang: Pustaka Mandiri.

Ahmad HP., \& Abdullah, A. (2010). Bahasa Indonesia untuk perguruan tinggi. Jakarta: Kencana.

Ahmad HP., \& Abdullah, A. (2012). Linguistik umum. Jakarta: Erlangga.

Kridalaksana, H. (2008). Kamus linguistik. Jakarta: PT Gramedia Pustaka Utama.

Kridalaksana, H. (2010). Pembentukan kata dalam bahasa Indonesia. Jakarta: PT Gramedia Pustaka Utama.

Kuntarto, N. M. (2013). Cermat dalam berbahasa teliti dalam berpikir. Jakarta: Mitra Wacana Media.

Mahsun. (2007). Metodologi penelitian bahasa. Jakarta: Raja Grafindo Persada.

Nurjayati, H. (2014). Analisis penggunaan singkatan pada judul berita di harian Jawa Pos edisi Oktober - November 2013. (Naskah Publikasi Ilmiah). Universitas Muhammadiyah Surakarta.

Semiawan, C. R. (2010). Metode Penelitian Kualitatif. Jakarta: Grasindo.

Tim Pengembang Pedoman Bahasa Indonesia. (2016). Pedoman umum ejaan bahasa Indonesia. Jakarta: Kementerian Pendidikan dan Kebudayaan.

Yunus, S. (2012). Jurnalistik terapan. Bogor: Ghalia Indonesia. 